\title{
The Reform of Multimedia Interactive Teaching in English Listening Course in Colleges and Universities
}

\author{
Jin Xiaoli \\ Chengdu Neusoft University, Chengdu, Sichuan Province, 611844
}

Keywords: English listening; multimedia teaching; interactive teaching

\begin{abstract}
As an important part of English teaching in colleges and universities, the effectiveness of English listening teaching activities has a crucial influence on students' English learning ability and application ability. Firstly, this paper gives a brief overview of the development of English teaching in colleges and universities. Then it analyzes the advantages of multimedia interactive teaching method in English teaching in colleges and universities. Finally, on the basis of summarizing the full text, this paper mainly probes into the multimedia interactive teaching reform method of English listening course in colleges and universities, aiming at providing reference for people who are concerned about this field.
\end{abstract}

With the development of China's national economy and the improvement of people's living standard, all circles have paid more and more attention to the application of education in China, especially the multimedia interactive teaching method in English listening teaching activities in colleges and universities. In the context of the continuous improvement of modern teaching level, the English teaching mode of colleges and universities, especially English listening teaching, is constantly being optimized and innovated. How to adopt more active and effective teaching methods in this process to strengthen the effect of English listening teaching has become one of the key points of teaching staff in related fields.

\section{Current Situation of College English Listening Teaching}

As the organizer and guide of English listening teaching in colleges and universities, the importance of teachers in classroom teaching is self-evident. The teaching level of teachers will directly affect students' understanding and mastery of English knowledge and learning methods. From the analysis of the actual situation of development, it can be concluded that the English listening teachers in most parts of China have adopted the traditional teaching mode. First, the teacher will lead the students to know the contents of the textbook. After that, they will play the listening material repeatedly, so that the students can listen and do the exercises. Finally, the teacher will check the answers and give explanation to the questions. This kind of teaching mode is difficult to leave a deep impression on the students, thus can not improve the teaching effect ${ }^{[1]}$.

English teaching activities have a long history in our country, and the teaching materials of English teaching activities in colleges and universities share a variety of characteristics. But at the same time, it can also develop English teaching materials with more forms and varieties, which makes it difficult for teachers to conduct material quality screening. In terms of the teaching of English listening in colleges and universities, most of the teaching materials have failed to be updated in a timely and effective way. The rationality of the teaching materials of listening teaching is poor, which leads to the difficulty and ineffective improvement in the practical application, thus it brings certain difficulties to the teaching work of teachers.

Influenced by teachers' teaching methods and listening materials, students' enthusiasm for English listening cannot be improved effectively. At the same time, in traditional English teaching activities, students tend to devote more energy to English words, grammar, reading and writing. There is less participation in training activities such as listening comprehension and oral expression. Students do not lay a solid foundation for the comprehensive development of English ability. Therefore, in the actual learning process, students have a strong psychological burden in the face of 
new knowledge learning, and gradually become a passive receiver of knowledge and information.

\section{Advantages of Multimedia Interactive Teaching Method}

In the multimedia interactive teaching method, both teachers and students can fully mobilize the resources within the multimedia network according to their actual needs. In this process, it can effectively break the limitation of time and space and improve the individual pertinence of listening materials. With the use of multimedia equipment, students and teachers, students and students, teachers and teachers, can communicate timely and effectively. In exchange for a different view of the same question, it helps the students, to think effectively, and to achieve the goal of improvement in the course of learning.

Different from the listening materials pf traditional teaching mode, multimedia interactive teaching method can be used to display both sound materials and video materials for students. This kind of teaching mode can show the teaching content more intuitively for students, so that students can better understand and accept it. In the multimedia interactive teaching method, students' hearing, vision and other different senses can be transferred simultaneously, so that students can gradually eliminate the hearing impairment and deepen their understanding of the problem.

The listening materials of multimedia interactive teaching method are stored directly in the network and the cloud. The teacher can input the key words into the search box according to the teaching theme of the class, so that relevant resources can be called in the database. The database will regularly update the data to provide students with more fresh and popular learning materials. And, in the process of listening, the teachers can also choose to play it according to the student's level of learning, a reasonable choice of 0.5, 0.75, 1, 1.25 and 1.5 times faster, to improve students' listening ability in a gradual way.

\section{Multimedia Interactive Teaching Reform of College English Listening Course}

According to the analysis and discussion above, it can be learned that the English listening teaching in colleges and universities in China is facing serious challenges. At the same time, the rational application of multimedia interactive teaching method can break the predicament of English listening teaching in colleges and universities, and help students improve their learning ability with a more scientific teaching mode. For example, universities in some regions of China have built a web-based multimedia interactive teaching platform based on Internet information technology. In the platform, the traditional teaching mode of Language Lab has been transformed into a new teaching mode of interactive audio-visual communication. The local English professional listening tutors have fully mobilized the network technology, modern information technology and multimedia interactive technology in the school, and reasonably realized the modern teaching development concept. In this kind of English listening learning platform, students can not only interact with teachers and other students in real time, but also complete self-study and self-examination in the way of human-computer interaction. The learning situation of students will be retained in the multimedia interactive platform in the form of data and information so that teachers can master the learning situation of students ${ }^{[3]}$.

The English listening teachers in colleges and universities can actively explore the methods of using multimedia interactive teaching mode through the model of teaching and research group. For example, the English teaching and research group of colleges and universities in a certain area of our country, through collective consultation and communication and cooperation with other college English teaching and research groups, has built a more comprehensive and systematic English audio video database in the multimedia interactive platform. Through the construction of this new data database, the local college English professional listening tutors classified and processed the listening materials in the database according to different grades and the learning characteristics of the students. In this way, students are provided with more targeted learning materials for their language learning. Under the guidance of teachers, students can choose suitable learning materials to study independently according to their learning needs. 
The main form of the traditional English listening test is the same as the classroom teaching form, and the content of the examination is mainly the teaching material in the course. This kind of examination mode has very limited effect on the improvement of students' ability, and it can't effectively test the true level of English listening ability of students. Under the guidance of multimedia interactive teaching method, teachers can optimize and upgrade course assessment and evaluation system. Various types of listening materials and the pronunciation of many different accents are incorporated into the multimedia interactive teaching platform. In the daily teaching stage, teachers give students sufficient independent study time, so that students can make rational use of resources in the database for training and review. In the formal examination, the teacher selects different types of listening materials and phonetic types from the database by means of random selection, so that the positive effect of multimedia interactive teaching method can be fully realized, and the purpose of testing students' listening learning results is truly achieved.

To sum up, multimedia interactive teaching method is based on multimedia, which provides more diversified teaching methods for teachers and students. Teachers of English majors in colleges and universities can provide students with more reasonable and authentic teaching situations through the rational application of multimedia interactive teaching methods, so as to fully arouse students' enthusiasm for learning and actively participate in the learning activities, then students' ability of listening can be improved.

\section{Acknowledgment}

Foundation Item: Field Item of Chengdu Neusoft University "Study on the Effectiveness of Speech Listening Training for Improving the Listening Proficiency of English Majors” (Item no.: NSUJG2018-020)

\section{References}

[1] Song Chang. “Teaching Practice Model of English Listening Based on Multimedia Network” [J]. Journal of Hubei Correspondence University, 2013, 30(05): 137-138+163.

[2] Li Mingyang. “Application of Multimedia Technology in College English Listening Teaching” [J]. English Teacher, 2015, 15(23): 116-117.

[3] Li Wenjia. "Research on College English Listening Teaching in Multimedia and Multi-modal Conditions" [J]. Overseas English, 2015(18): 43-44. 